\title{
鉛直壁による波群の反射について

\author{
Reflection of Wave Groups from a Vertical Wall
}

\author{
喜岡 渉 $^{1} \cdot$ 北野利 $^{2} \cdot$ 肥後克紀 ${ }^{3}$ \\ Wataru KIOKA, Toshikazu KITANO and Katsunori HIGO
}

\begin{abstract}
The third-order interactions between the normal incident and reflected wave groups due to a vertical wall are investigated by numerical simulations based on Zakharov's equations with kernel functions valid for the cases of finite depth. The amplitude modulation occurs due to the unstable disturbance of class I for water depths except for near $k h=1.36$. The results of the temporal surface elevations computed on the basis of Zakharov's equation indicate that in intermediate water depths nonlinear waves both having side-band disturbance and bimodal spectrum undergo strong modulation and their maximum wave height in the group increases with time above the initial height. The changes in phase velocity of the reflected wave groups are also significant.
\end{abstract}

\section{1. はじめに}

Molinら（2005）は，深海の水面に固定された箱型浮 体（長さ $5 \mathrm{~m}$, 幅 $1.2 \mathrm{~m}$, 契水深 $0.24 \mathrm{~m}$ ) に不規則波（有義 波高 $H_{s}=0.15 \mathrm{~m}$, ピーク周期 $T_{p}=1.6 \mathrm{~s}$, ピーク形状パラメー 夕 $\gamma=1$ ) を直角入射させ, 入射側の浮体中央部付近の波 高は他の場所と比べて 2 倍以上, 線形回折波理論值と比 べると 3 倍以上大きくなり，かつ入射側中央部付近では 波形の位相が若干遅れることを示し, 反射領域における こうした変調・増幅現象は入射波の波形勾配 $H / L>0.03$ で 現れ, 入反射波の非線形干渉により生じることを示唆し た. 喜岡ら (2008) は, 中間水深 $(h / L=0.2 \sim 0.3)$ にお ける鉛直壁からの規則波と波群の反射実験を行い，規則 波では入射波の波形勾配 $H / L>0.05$, 波群については $H / L>0.04$ （ただし，Hは入射波群中の最大波高）で位相 の遅れが生じ, 波群中の最大波の波高や打上げ高は有限 振幅波理論值を大きく上回ることを示した。この波群変 形は，弱非線形の波群の反射を扱った喜岡ら（1996）お よび筧田・水口（1997）の理論では説明できない.

本研究は, 波群が鉛直壁により完全反射するときの波 高の増大と位相遅れの現象を説明し得る最低次数の数值 モデル, すなわち3次オーダーの4波相互干渉モデルを 用いた数值解析を行い, 波群中の最大波の波高に及ぼす 非線形相互作用の影響を調べ，増幅が生じる入射条件を 明らかにしょうとするものである。

\section{Zakharov 方程式モデル}

有限水深下での波列のゆっくりとした時間変動を記述 する, 微小パラメータとについて 3 次オーダーのZakharov

\begin{tabular}{llll}
\hline 1 & フェロー & Ph.D. & 名古屋工業大学教授 大学院工学研究科 \\
2 & 正会員 & 博(工) & 名古屋工業大学准教授 大学院工学研究科 \\
3 & & 工修 & 愛知県道路公社建設部
\end{tabular}

積分方程式 (Stiassnie - Shemer, 1984）は，次式のように 表すことができる.

$$
\begin{gathered}
i \frac{d B_{j}}{d t}=T\left(\mathbf{k}_{j}, \mathbf{k}_{j}, \mathbf{k}_{j}, \mathbf{k}_{j}\right)\left|B_{j}\right|^{2} B_{j}+\sum_{n \neq j} 2 T\left(\mathbf{k}_{j}, \mathbf{k}_{n}, \mathbf{k}_{j}, \mathbf{k}_{n}\right)\left|B_{n}\right|^{2} B_{j} \\
+\sum_{\substack{p, q \neq j \\
2 \mathbf{k}_{j}=\mathbf{k}_{p}+\mathbf{k}_{q}}} T\left(\mathbf{k}_{j}, \mathbf{k}_{j}, \mathbf{k}_{p}, \mathbf{k}_{q}\right) B_{j}^{*} B_{p} B_{q} \exp \left\{i\left(2 \omega_{j}-\omega_{p}-\omega_{q}\right) t\right\} \\
+\sum_{\substack{n, p, q \neq j \\
\mathbf{k}_{n}+\mathbf{k}_{j}=\mathbf{k}_{p}+\mathbf{k}_{q}}}\left(\mathbf{k}_{j}, \mathbf{k}_{n}, \mathbf{k}_{p}, \mathbf{k}_{q}\right) B_{n}^{*} B_{p} B_{q} \exp \left\{i\left(\omega_{j}+\omega_{n}-\omega_{p}-\omega_{q}\right) t\right\} \\
(n, j, p, q=1,2, \ldots N)
\end{gathered}
$$

ここに, *は複素共役を示し, 複素振幅 $B$ は水位変動と 次の関係にある。

$$
\begin{gathered}
\eta(\mathbf{x}, t)=\frac{1}{2 \pi} \int_{-\infty}^{\infty}\left(\frac{\omega(|\mathbf{k}|)}{2 g}\right)^{1 / 2}[B(\mathbf{k}, t) \\
\left.\times \exp \{i(\mathbf{k} \cdot \mathbf{x}-\omega(|\mathbf{k}|) t)\}+{ }^{*}\right] d \mathbf{k}
\end{gathered}
$$

式（1）の右辺第 3 項, 第 4 項の波数各成分に対応する角 周波数 $\omega$ は, 次の共鳴近傍条件を満たすものである.

$$
\left|\omega_{j}+\omega_{n}-\omega_{p}-\omega_{q}\right| \leq 0\left(\varepsilon^{2}\right)
$$

複素振幅 $B$ は自由波のもので, $\varepsilon^{2}$ およ゙ $\varepsilon^{3}$ オーダーの 次式 (4), (5) で与えられる複素振幅 $B^{\prime}, B$ '”の拘束波が それぞれ励起される。

$$
\begin{aligned}
& i \frac{d B_{j}^{\prime}}{d t}=\sum_{\mathbf{k}_{j}=\mathbf{k}_{p}+\mathbf{k}_{q}} V^{(1)}\left(\mathbf{k}_{j}, \mathbf{k}_{p}, \mathbf{k}_{q}\right) B_{p} B_{q} \exp \left\{i\left(\omega_{j}-\omega_{p}-\omega_{q}\right) t\right\} \\
& +\sum_{\mathbf{k}_{j}=-\mathbf{k}_{p}+\mathbf{k}_{q}} V^{(2)}\left(\mathbf{k}_{j}, \mathbf{k}_{p}, \mathbf{k}_{q}\right) B_{p}^{*} B_{q} \exp \left\{i\left(\omega_{j}+\omega_{p}-\omega_{q}\right) t\right\} \\
& +\sum_{\mathbf{k}_{j}=-\mathbf{k}_{p}-\mathbf{k}_{q}} V^{(3)}\left(\mathbf{k}_{j}, \mathbf{k}_{p}, \mathbf{k}_{q}\right) B_{p}^{*} B_{q}^{*} \exp \left\{i\left(\omega_{j}+\omega_{p}+\omega_{q}\right) t\right\}
\end{aligned} .
$$




$$
\begin{aligned}
i \frac{d B_{j}^{\prime \prime}}{d t}=\sum_{\mathbf{k}_{n}+\mathbf{k}_{j}=\mathbf{k}_{p}+\mathbf{k}_{q}}\left(\mathbf{k}_{j}, \mathbf{k}_{n}, \mathbf{k}_{p}, \mathbf{k}_{q}\right) B_{n}^{*} B_{p} B_{q} \\
\\
\quad \times \exp \left\{i\left(\omega_{j}+\omega_{n}-\omega_{p}-\omega_{q}\right) t\right\}
\end{aligned}
$$

拘束波成分の $B{ }^{\prime}, B$ "の時間変動は $B$ に比べると相当に 速いので，両式はStiassnie・Shemer（1987）のように $t に$ ついて積分した式に書き換えることができるが，ここで はBの変動が大きく拘束波の時間スケールでも一定と見 なせないケースも扱うことから, 両式も数值積分によっ て求めた。式（5）の計算に扔いては，式（3）の共鳴近 傍条件を満たす波数の組合せは除外される。なお，式 (1)，(4)，(5) 中の核関数 $T, V^{(1),(2),(3)}$ にはStiassnie · Shemer（1984）ならびにMase・Iwagaki（1986）によっ て与えられている関数式を用いた.

\section{3. 側帯波モード}

波数 $\mathrm{k}$ の波に $\mathrm{k} \pm p$ の振幅の小さい側帯波を加えて入射 波群とし，鉛直壁で完全反射する1次元伝播を考える. すなわち, $\mathbf{k}_{1}=\mathrm{k}_{0}(1,0), \mathbf{k}_{2}=\mathrm{k}_{0}(1+\mathrm{p}, 0), \mathbf{k}_{3}=\mathrm{k}_{0}(1-\mathrm{p}, 0)$, $\mathbf{k}_{4}=-\mathbf{k}_{1}, \mathbf{k}_{5}=-\mathbf{k}_{2}, \mathbf{k}_{\mathbf{6}}=-\mathbf{k}_{3}$ の6成分を用い, $\mathbf{k}_{1}, \mathbf{k}_{4}$ の初期振幅を $a_{0}$, 側带波成分については $\varepsilon a_{0}$, それぞれの初期位相角を $0, \theta_{\mathrm{I}}, \theta_{\mathrm{II}}$ とし，複素振幅 $B(\mathbf{k}, \mathrm{t})$ を2.に示した有限水深に 拡張したZakharov方程式モデルより求めた。側帯波の $p$ は $0<p<1.5, \mathrm{k}_{0}=1$ として,$a_{0}$ は $0.1 \sim 0.2, \varepsilon$ は $0.05 \sim 0.2$, 位相角 $\theta_{\mathrm{I}}, \theta_{\mathrm{II}}$ は $0, \pm 4 / \pi$, 相対水深は $h=0.5,1.0,1.5,2.0$ の 4 種類とし各成分の振幅変調を計算した。

図-1 (b)に示すように，重複波（6モード）の各成分に おいても (a)の進行波（3モード）と同様な周期で再帰性

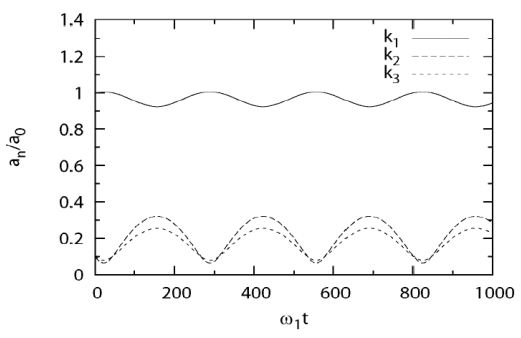

（a）進行波3モード

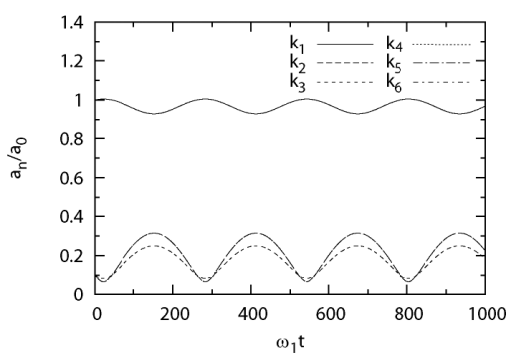

(b) 重複波6モード

図-1 振幅変調 $\left(h=1.0, p=0.1, a_{0}=0.2, \varepsilon=0.1, \theta_{1}=\theta_{\mathrm{II}}=-4 / \pi\right)$
が見られ， $\mathbf{k}_{1}$ と $\mathbf{k}_{4}, \mathbf{k}_{2}$ と $\mathbf{k}_{5}, \mathbf{k}_{3}$ と $\mathbf{k}_{6}$ は対称で，振幅は常 に等しい。詳しく見ると，側带波 $\mathbf{k}_{2}, \mathbf{k}_{5}$ の最大振幅の方 が側帯波 $\mathbf{k}_{3}, \mathbf{k}_{6}$ より常に大きい。側帯波の $p$ の増加とと もに振幅変調は小さくなり, この水深 $h=1.0$ では $p>0.45$ の高調波 $p=1.3$ 付近を除いて振幅は初期值と変わらず一 定值をとり，振幅変調は起こらない．図-2に示す $p=1.3$ 付近の変調を除けば，重複波モードの変動周期，最大お よび最小振幅は進行波モードとほぼ一致する。

図には示さないが，相対水深が $h=0.5$ と浅くなると振 幅の変動周期はさらに短くなり， $\omega_{1} t<80$ の間隔で再帰性 が見られるようになる．側帯波の最大振幅は $h=1.0$ のと きょり若干大きくなる. 水深 $h=1.5$ では再帰間隔は $\omega_{1} t=1800$ と極めて長くなり,$p<0.1$ を除いて有意な振幅変 調は現れなくなる。ささらに哚く $h=2.0$ になると再帰間隔 は幾分短くなり，振幅の変動も大きく現れる（図-3)。こ のケースでは，重複波の再帰間隔の方が幾分長くなって いる．すなわち，水深に関しては進行波と同様に，波の 線形性が理論的に最も強まる $h=1.36$ に近い $h=1.5$ のケー スを除いて，再帰性を伴う有意な振幅変調が起こる。

図-4 (a)に示すように，側带波の振幅を大きくすると， 図-1 (b) と比べて変動周期は短く現れ，振幅の変調幅は より大きくなる．初期振幅 $a_{0}$ を小さくすると, 図-4 (b) に示すように, 変動周期はより長く, 振幅変調は小さく 現れる。初期位相は振幅の変調幅や周期には影響を与え ず，位相のずれのみが生じる (図-4 (c)) .

重複波 6 モードの振幅変動の 1 周期に打ける最大值を 読从取り， $a_{0}=0.2$ のケースについて側带波 $\mathbf{k}_{2}, \mathbf{k}_{5}$ 成分の $p$ に対する最大振幅を示したものが図-5である。この最大

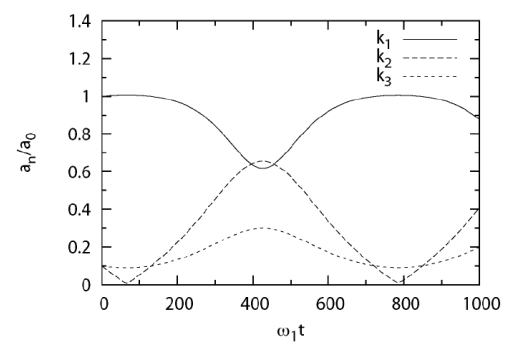

（a）進行波3モード

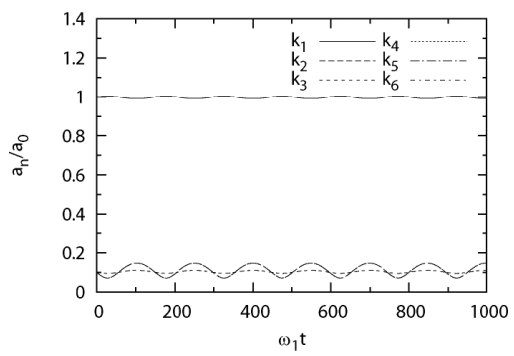

(b) 重複波6モード

図-2 振幅変調 $\left(h=1.0, p=1,25, a_{0}=0.2, \varepsilon=0.1, \theta_{\mathrm{I}}=\theta_{\mathrm{II}}=-4 / \pi\right)$ 


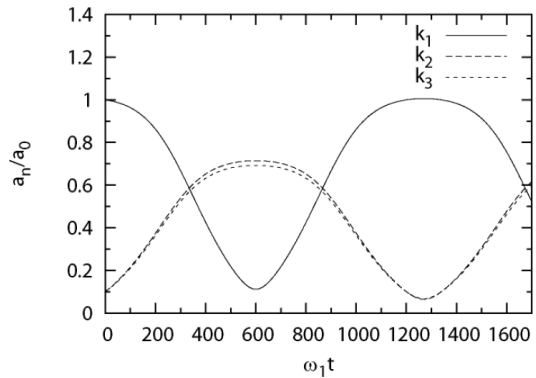

(a) 進行波3モード

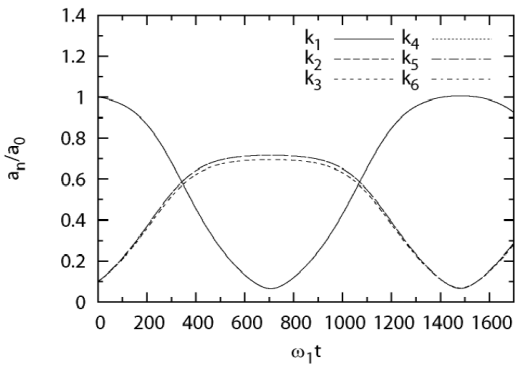

(b) 重複波6モード

図-3 振幅変調 $\left(h=2.0, p=0.1, a_{0}=0.2, \varepsilon=0.1, \theta_{\mathrm{I}}=\theta_{\mathrm{II}}=-4 / \pi\right)$

振幅は側帯波 $\mathbf{k}_{3}, \mathbf{k}_{6}$ 成分より常に大きい. 最大振幅が大 きいほど共鳴近傍干渉による振幅変調が著しく現れ，一 方で初期振幅 $a_{2,5} / a_{0}=0.1$ と変わらない $p$ の領域においては 非線形干渉による振幅変調は起こらない。ただし, 図中 の $h=0.5$ の $p<0.8$ における変調幅は式（3）の共鳴近傍条 件を厳しく $\left(\varepsilon \approx a_{0} \mathrm{k}\right.$ の值を計算条件より小さく $)$ とると 抑制されるので，他の相対水深における側帯波モードと の共鳴干渉とは異なる現象である。

\section{4. 多成分解析}

側帯波成分 $\mathrm{k}_{0}(1+\mathrm{p}) ， \mathrm{k}_{0}(1+\mathrm{p})$ を含む $-4 \mathrm{k}_{0}$ から $4 \mathrm{k}_{0}$ の波 数を $N=160$ 分割して, 重複波の $B$ に加えて, 2 次オーダー の拘束波成分 $B^{\prime}, 3$ 次オーダーの共鳴近傍を除く拘束波 成分 $B$ ”をそれぞれ式（4）および（5）により計算して, $\left(B+B^{\prime}+B^{\prime \prime}\right)$ を水位変動に換算して時間波形を求めた.

図-6（b)は，波群重複波において著しい波高増大が見 られた計算結果の一例で，進行波の時間波形と比較した ものである．波群は時間とともに前傾し，かつ尖鋭化し ている. 時間 $\omega_{1} t=320$ 付近で重複波の波高は最大になり, この位相は図-3 (b) で基本波成分と側带波成分の振幅が ほぼ等しくなる $\omega_{1} t$ に一致している. 図-6 (a)の進行波と 比べて位相速度は遅くなり, 波群周期は若干長くなる。 このケースでは，図-7に示すように重複波のスペクトル は時間とともに高波数側に広く分布し，主として拘束波 $B$ ’の寄与により波高が増大する。同様な条件下で重複波 群の極大化が生じることは造波水路実験（喜岡ら，2008）

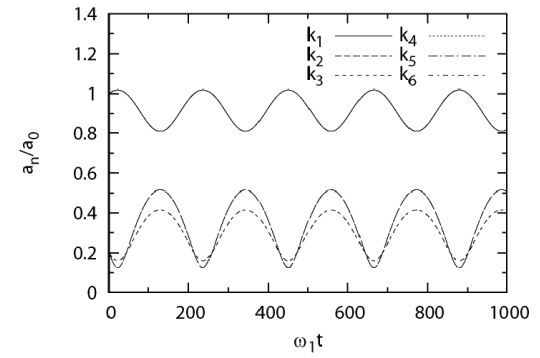

(a) $h=1.0, p=0.1, a_{0}=0.2, \varepsilon=0.2, \theta_{\mathrm{I}}=\theta_{\mathrm{II}}=-4 / \pi$

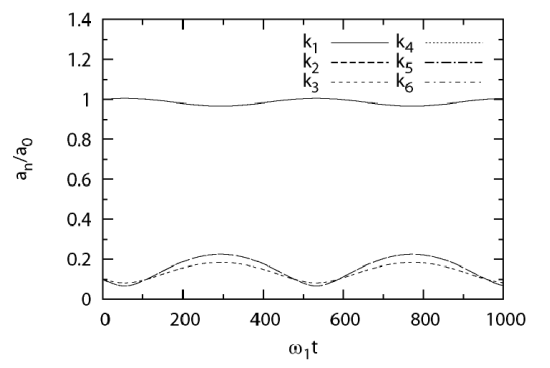

(b) $h=1.0, p=0.1, a_{0}=0.12, \varepsilon=0.1, \theta_{\mathrm{I}}=\theta_{\mathrm{II}}=-4 / \pi$

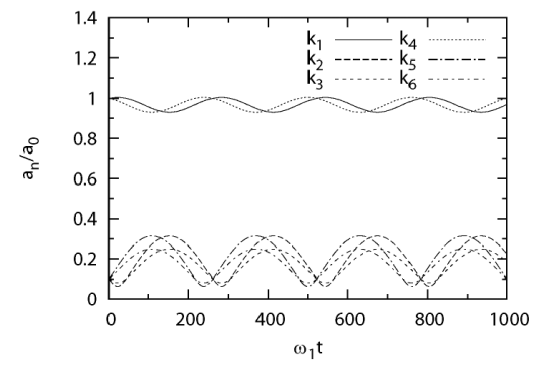

(c) $h=1.0, p=0.1, a_{0}=0.2, \varepsilon=0.1, \theta_{\mathrm{I}}=-4 / \pi, \theta_{\mathrm{II}}=4 / \pi$

図-4 重複波の振幅変調

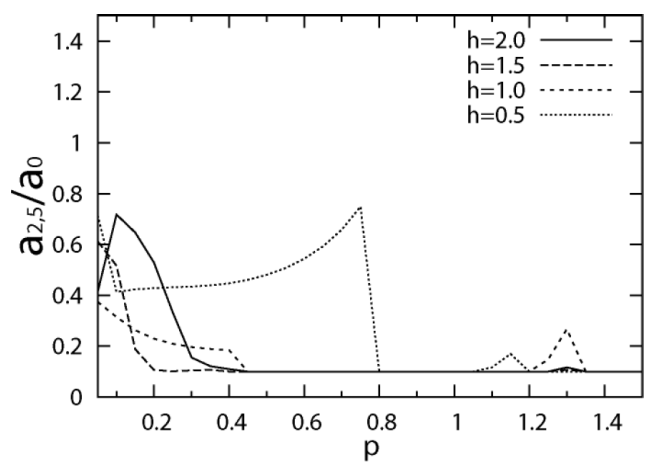

図-5 側帯波 $\mathbf{k}_{2}, \mathbf{k}_{5}$ の最大振幅 $\left(a_{0}=0.2, \varepsilon=0.1, \theta_{\mathrm{I}}=\theta_{\mathrm{II}}=-4 / \pi\right)$

によっても確かめられているが，実験においては極大化 の直後に哗波が生じており, ここで用いた3次オーダー の理論では砕波限界付近の極大波を再現することはでき ない，波頂高が砕波限界に近いケースについては，より 高次の非線形干渉モデルによる検証が必要である.

図-8 (a), (b) に非線形干渉による振幅変調が比較的穏や かな相対水深 $h=1.5$ の計算結果を示す. 規則的な重複波 


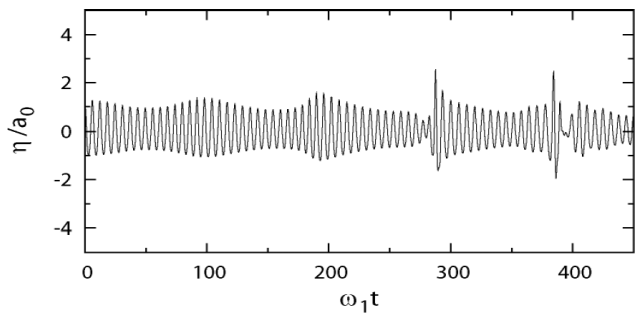

(a) 波群進行波

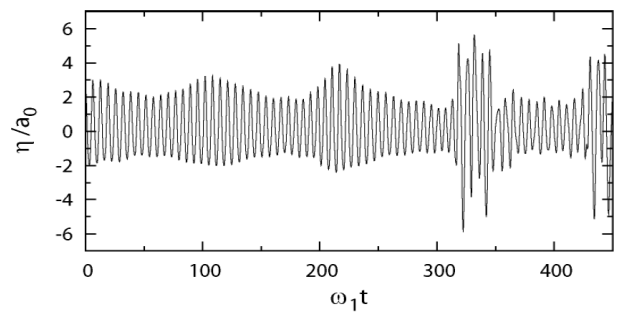

(b) 波群重複波

図-6 波群の時間発展 $\left(h=2.0, p=0.1, a_{0}=0.2, \varepsilon=0.1\right)$

群が形成されており，入射振幅の小さい(b)ではほぼ前 後対称の波群が生じている. 図-8 (c) は振幅変調が全く 現れない $h=2.0, p=0.5$ の計算結果で，このときの波高変 動は主に基本自由波の波数和と差の拘束波成分 $B$ 'と 3 次 のB”による，図-8に示したケースにおいては，図-6のよ うな波群中の波高の極大化は現れない.

これら波群中の最大波頂高 $\eta_{\text {max }}$ を入射振幅 $a=a_{0}(1+2 \varepsilon)$ で除して，ストークス重複波第3次近似解と比較したも のを図-9に示す。図中の白抜き記号は，非線形干渉によ る振幅変調が生じない側帯波 $p$ を選んだケースの最大波 頂高を示し，波高増幅は自由波の波数和と差の拘束波に よって生じ，ストークス重複波理論に近い值をとってい る. 最大波頂高は, $h=1.36$ 付近を除く相対水深において 側帯波が $p<0.4$ の值をとるとき，入射振幅 $a_{0}$ が大きいか 側帯波の振幅 $\varepsilon a_{0}$ が大きいほど，ストークス重複波理論 值を大きく上回る。

次に, バンド幅パラメータ $m=20$ としたWallops型波数 スペクトルにより初期スペクトルを与え（安田ら，1995）, $30 T_{p}$ （ $T_{p}$ はピーク波数 $k_{p}$ に対応するピーク周期）進行後 の $B$ を入射波群として $100 T_{p}$ 後の $B$ および拘束波 $B^{\prime}$ 'を初期 位相角 3 通りに対して計算し，その平均をとって重複波 のスペクトルを求めた.

ピーク波数 $k_{p}=1$ として, $H_{s}=0.24$ すなわち波形勾配 $a k_{p}=0.12\left(a=H_{s} / 2\right)$, 水深は $h=1.0,2.0$ の 2 通り, 計算領 域を $-4 k_{p}$ から $+4 k_{p}$ とし成分数 $N=1024$ (入射波領域につい て $N=512 ）$ を用いた。計算時間の都合上，拘束波成分は 2次オーダーB'についてのみ求めた。図-10 (b) の $h=1.0$ の 波数スペクトルは (a)の $h=2.0$ の分布と比べて，低波数領

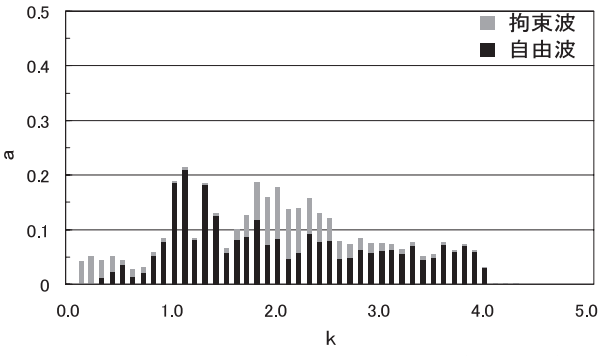

図-7 波群重複波の振幅スペクトル（ $\omega_{1} t=430 ）$

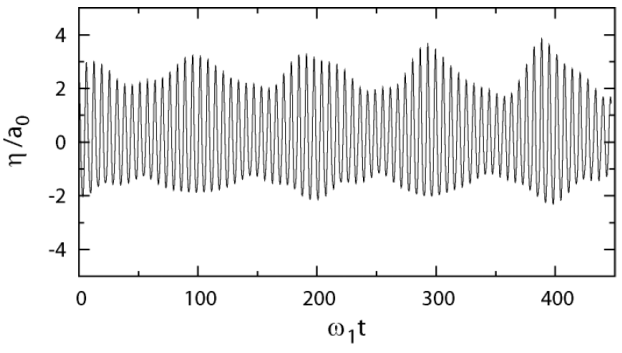

(a) $h=1.5, p=0.1, a_{0}=0.2, \varepsilon=0.1$

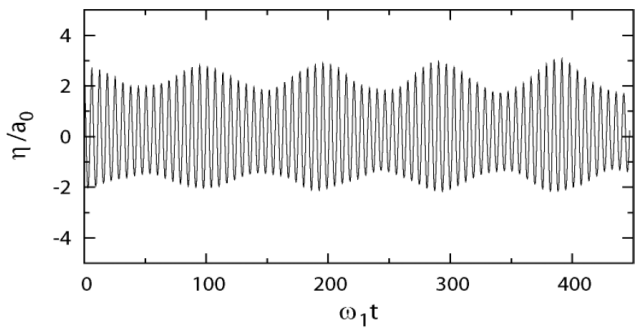

(b) $h=1.5, p=0.1, a_{0}=0.12, \varepsilon=0.1$

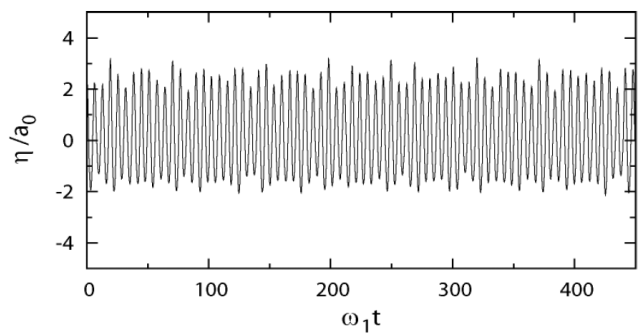

(c) $h=2.0, p=0.5, a_{0}=0.2, \varepsilon=0.1$

図-8 波群重複波の時間発展

域と $k / k_{p}=2.0$ 付近で増幅している.また，(b) の $h=1.0$ の ケースでは, $k / k_{p}>2.0$ の高波数領域において初期スペク トルと比べて緩い勾配に変形しており，高次干渉理論に よる安田ら（1995）の進行波のスペクトル計算結果と同 様な変形特性を示している。

最大波頂高 $\eta_{\text {max }} / H_{s}$ は，相対水深 $h=1.0,2.0$ についてそれ ぞれ $1.95,1.47$ となり，不規則波群の個々波に有限振幅 波理論（ストークス第3次近似解）を用いて求めた值を 


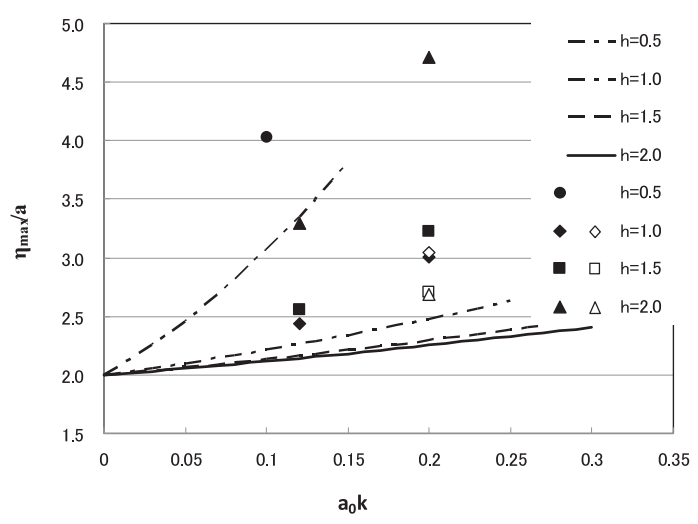

図-9 波群重複波の最大波頂高（曲線はストークス重複波理 論第3 次近似解)

表-1 波頂高および平均連長

\begin{tabular}{c|c|c}
\hline & $h=2.0$ & $h=1.0$ \\
\hline$\eta_{\max } / H_{s}$ & 1.47 & 1.95 \\
\hline $\bar{j}_{l}\left(H_{c}=2 H_{s}\right)$ & 1.78 & 1.72 \\
\hline $\bar{j}_{1}\left(H_{c}=2 H_{\text {med }}\right)$ & 2.86 & 3.04 \\
\hline
\end{tabular}

ともに上回る. $100 T_{p}$ 後の波列から, $H_{c}=2 H_{s}$ および $H_{c}=2$ $H_{m e d}$ (ただし, 中央值 $H_{m e d}$ は $30 T_{p}$ 進行後の入射波の波高 值）以上の波高をもつ不規則波群中の連長を求め, 平均 をとった結果を表-1に示す， $H_{m e d}$ で定義した平均連長 $\bar{j}_{1}$ は $h=1.0$ のケースで若干長く現れており, 波群形状が $h=1.0$ では扁平化することを示唆している.

\section{5. おわりに}

中間水深においてはピーク波数 $\mathrm{k} に$ 対して側帯波の波 数 $\mathrm{k} \pm p$ が $p<0.2$, すなわち 5 波以上の波群長をもつよう な波が入射するとき，非線形干涉により鉛直壁前面にお ける波頂高は極めて大きくなる。このとき, 波群の個々 波を有限振幅波と見なす解析では，打上げ高などを過小 に算定する. しかし，入射波の波形勾配が $a_{0} k=0.2$ 程度で も波頂高の計算結果は砕波限界の重複波に近く, より高 次の非線形干渉モデルや実験による検証が必要である.

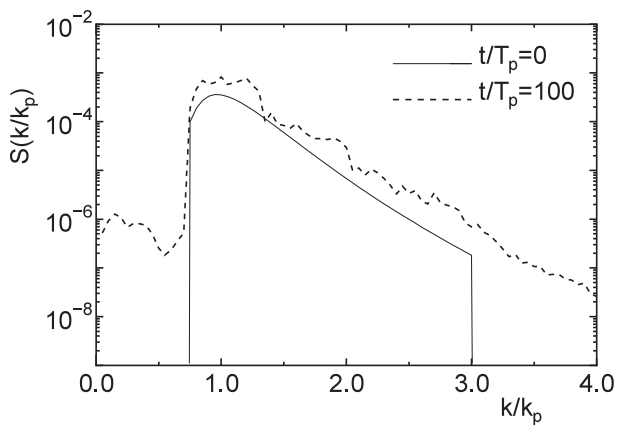

(a) $h=2.0$

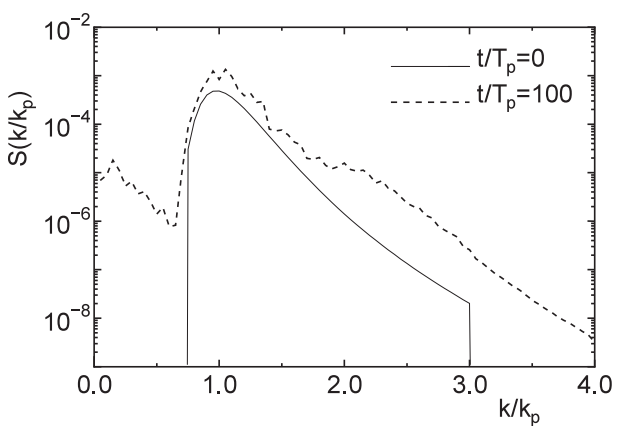

(b) $h=1.0$

図-10 100 $T_{p}$ 後のスペクトル分布

\section{参 考 文 献}

喜岡 渉・山根 聡・青木伸一（1996）：波群とそれに伴う長 周期波の反射, 海岸工学論文集, 第43巻, pp.166-170.

喜岡 渉・岩塚雄大・肥後克紀・北野利一 (2008) : 鉛直壁か らの強非線形波の反射について, 海岸工学論文集, 第 55 巻, pp.11-15.

筧田博章・水口 優（1997）：波群の反射と長周期波，海岸工 学論文集, 第 44 巻, pp.201-205.

安田孝志・森 信人・加藤 茂（1995）：不規則波列の波群諸 量に及ぼす高次干渉と浅水化の影響，第42巻，pp.276-280.

Mase, H. and Y. Iwagaki (1986) : Wave group analysis of nature wind waves based on modulational instability theory, Coastal Engineering, Vol.10, pp.341-354.

Molin, B., F. Remy, O. Kimmoun and E. Jamois (2005) : The role of tertiary wave interactions in wave-body problems, J. Fluid Mech., Vol.528, pp.323-354.

Stiassnie, M. and L. Shemer (1984) : On modifications of the Zakharov equation for surface gravity waves, J. Fluid Mech., Vol.143, pp.47-67.

Stiassnie, M. and L. Shemer (1987) : Energy computations for evolution of class I and II instabilities of Stokes waves, J. Fluid Mech., Vol 174, pp 299-312. 